\title{
ENTRAMADOS REBELDES DE PUNA Y VALLES EN EL TUCUMÁN (SIGLO XVII). VALLE DE LONDRES, PROVINCIA DE LOS DIAGUITAS. UNA PERSPECTIVA CARTOGRÁFICA
}

\author{
REBELS OF THE PUNA AND VALLEYS IN TUCUMÁN (XVII \\ CENTURY) IN THE LONDON VALLEY, LOS DIAGUITAS \\ PROVINCE: A CARTOGRAPHIC PERSPECTIVE
}

Laura Quiroga ${ }^{1}$

\begin{abstract}
Resumen
A través de la cartografía jesuítica de las provincias del Paraguay y Tucumán se propone analizar la conformación del paisaje y sociedad colonial en la jurisdicción de Londres (Gobernación del Tucumán). Se plantea que esta pieza cartográfica, publicada en 1662, representa la dinámica política, de alianzas y liderazgos entre las áreas puneña y cordillerana de la gobernación. La alianza formada por los curacas

de Antofagasta con los de Malfin, Andalgalá y Abaucán constituye un entramado rebelde con una dinámica propia respecto de los alzamientos de gran escala liderados por los calchaquíes que habitaron la Gobernación del Tucumán.
\end{abstract}

Palabras claves: Cartografía colonial - jesuitas - alianzas - resistencia - asentamiento. Through the Jesuit cartography of the Paraguay and Tucumán provinces, we analyze the colonial scene in a jurisdiction called London (located within the Tucumán province). It is said that this cartographic piece, published in 1662 , represents the dynamic policy of alliance and leadership among the "puna" and Andean provincial regions. The alliance was formed by the curacas of Antofagasta, and together with the Malfin, Andalgala and Abaucan groups, they formed a dynamic rebel structure involved in large-scale uprisings. These were headed by the "calchaquíes" people who inhabited the Tucumán Governorship.

Keywords: Colonial cartography - Jesuit - alliances - resistance settlement.

Recibido: diciembre 2015. Aceptado: abril 2017.

\section{* Introducción}

La producción cartográfica de la Orden jesuita sobre el Río de la Plata, compilada por Guillermo Furlong (1936: 26-30) contiene un mapa de las Provincias jesuíticas del Paraguay y Tucumán de 1647, señalado por el autor, como el plano más detallado del conjunto (Figura 1). La obra, compuesta por dos volúmenes, incluía un tomo de reproducciones en blanco y negro, precedido de un comentario crítico respecto de ediciones, año y autoría de cada pieza cartográfica. En los casos en los que el mapa carecía de firma y fecha, Furlong asignó una autoría individual sobre la base de inferencias documentales indirectas.

Diversos investigadores del área cordillerana de la gobernación utilizaron este mapa para ubicar en el terreno referencias sobre pueblos y localidades, etnias, señoríos o parcialidades mencionadas en la documentación. Entre ellos podemos señalar los trabajos de Raffino (1988), Haber (2003), Haber y Lema (2006), Quiroga (2003), Giudicelli (2009), Lema (2012). Los trabajos de Raffino (1983) y Lema (2012: 105) prestan atención a las variaciones observadas en la tipografía del área cordillerana de la Gobernación del Tucumán, sin embargo, una observación detenida y crítica de los recursos visuales utilizados por quienes elaboraron esta pieza cartográfica, más que ofrecernos anclajes territoriales precisos a las denominaciones que se encuentran en los textos coloniales, tal como los autores señalan en sus escritos, nos permite generar nuevos interrogantes.

1 Pertenencia institucional: CONICET-UBA. Dirección postal: Díaz Vélez $3555^{\circ}$ D. CABA (1200). ARGENTINA.

Email:cotagua@yahoo.com.ar 


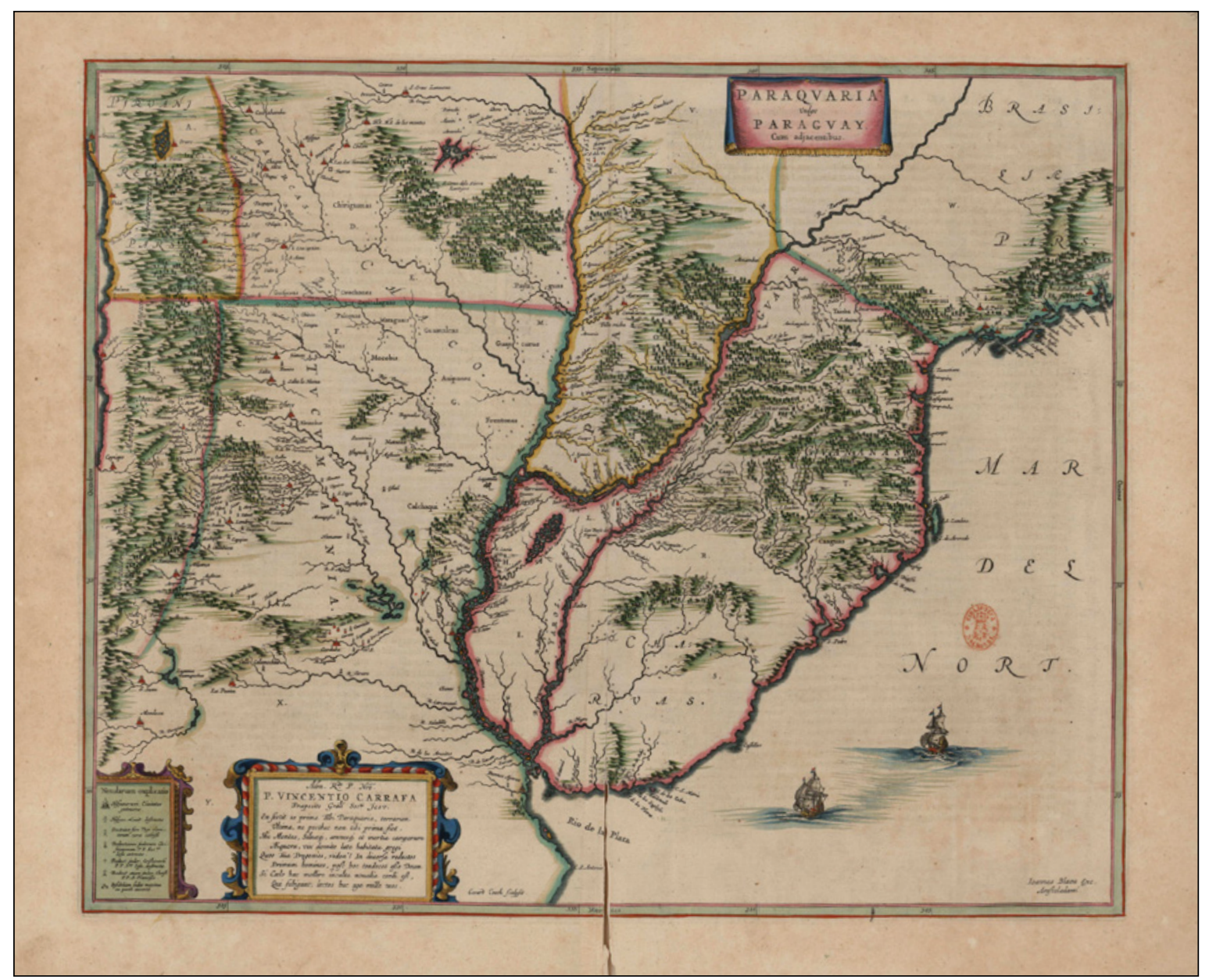

Figura 1. Paraquaria/vulgo/Paraguay/cum Adjacentibus. En: America, quae est Geographiae Blavianae: Pars Quinta, Liber Unus. Volumen Undecimum. Amsteladami, 1662. Reproducido de la Biblioteca Nacional de España.

Desde los inicios del siglo XX los investigadores propusieron diversos criterios tales como categorías identitarias, topónimos y clasificaciones coloniales, entre otros, para describir e interpretar la dinámica social y política de los nativos de la Gobernación de Tucumán a partir de la lectura crítica de la documentación escrita (Cruz 1997; Giudicelli 2008; Lorandi y Boixados 1987-88). La cartografía sirvió para sintetizar y expresar en forma visual las conclusiones elaboradas desde el trabajo documental; sin embargo, la producción cartográfica de los siglos XVI y XVII quedó al margen del debate sobre el significado de las denominaciones coloniales como dispositivos de poder y control social. De esta forma, si el análisis de los textos encuentra en la cartografía un asidero para sus conclusiones, propongo abordar este problema siguiendo el camino inverso: tomar la cartografía colonial como fuente histórica, buscando en la representación visual una alternativa a la perspectiva que arrojan los documentos escritos (Harley 2005; Cosgrove 2008).

La construcción política de los paisajes en el contexto de una sociedad colonial en formación encierra conflictos sobre la tierra y a través de la tierra (Sluyter 2002). La materialidad de los paisajes es un componente imprescindible en el tejido de una trama en la que se involucran por igual actores y escenarios, transformando lugares, geografías y ambientes en un problema histórico (Arnold 2000; Ingold 2007, Sluyter 2002, Scott 2006). Sin embargo, interpretar el paisaje en términos de materialidad supone reconocer la agencia de los espacios y ambientes que se transitan, recorren y describen. En otras palabras, "la tierra" resulta no solo un escenario de los relatos sino 
también un actor que construye otros actores. En este contexto, los mapas son parte activa y constitutiva del proceso político que crea el territorio, no solo su representación (Craib 2000; Hunter y Sluyter 2011).

El análisis de procesos históricos desde la representación cartográfica parte del supuesto de una relación dialéctica entre imagen y poder (Harley 2005, Cosgrove 2008, Lois 2000). El mapa expresa por medio de una arquitectura visual de signos, la relación espacial de sus componentes, superponiendo estructuras de conocimiento que tienen la capacidad de crear y recrear los imaginarios en torno al paisaje (Lois 2014; Cosgrove 2008). En términos de una estrategia metodológica Harley (2005) plantea un análisis contextual y comparativo que ubique la pieza cartográfica en el conjunto de la producción de su tiempo, así como en el entorno institucional del que proviene y el impacto que produce en la construcción de imaginarios sobre el mundo. La riqueza del planteamiento del autor se amplía al incorporar la noción de silencios cartográficos para referirse a aquellos aspectos que, por omisión, resultan tan elocuentes como los rasgos formales presentes y jerarquizados en el mapa.

El ícono-texto se refiere a aquellas formas de expresión gráfica conformadas por la articulación espacial de textos e imágenes (Cosgrove 2008). De modo que el análisis incluye una dimensión textual que comprende no solo referencias a lugares, denominaciones u otras etiquetas, sino que el mapa se analiza desde la estética de la escritura cartográfica, incluyendo en este campo aspectos tales como tipografía, densidad y las redes espaciales que crean la presencia de rótulos indicativos (Lois 2010). Me refiero no solo a aquello que dicen los rótulos, sino cómo se expresan significados desde su análisis formal-visual.

Partiendo de estas consideraciones teóricas sobre el significado de los rótulos en la cartografía, podemos señalar que la generalización del nombre calchaquí como centro de los movimientos de resistencia opacó la alianza formada por los curacas de Antofagasta con los de Malfin, Andalgalá y Abaucán como un entramado rebelde capaz de presentar una dinámica propia respecto de los alzamientos liderados por los calchaquíes durante los siglos XVI y XVII. El mapa jesuítico a través de la distribución de rótulos, junto a otros rasgos formales de los signos cartográficos, representa la territorialidad de un entramado rebelde que articulaba entre sí poblaciones puneñas y vallistas. Por tanto sostengo que la cartografía jesuítica de 1647 contiene, efectivamente, información muy detalla$\mathrm{da}$, pero no se trata de una toponimia precisa de regiones poco conocidas, sino de la dinámica política, de alianzas y liderazgos entre las áreas puneña y cordillerana de la Gobernación del Tucumán. Entonces, partiremos de una revisión crítica de la cartografía producida por la historiografía regional -incluyendo en el conjunto la producción cartográfica antropológica- para abordar finalmente, los mapas coloniales de la región. Sobre esta base teórica y metodológica quiero analizar la conformación del paisaje colonial en la jurisdicción de Londres, con el fin de problematizar la representación cartográfica. Partiendo de los mapas que acompañan la historiografía regional andaremos el camino en sentido inverso, desde la cartografía colonial abordaremos la documentación escrita.

\section{* Mapas Étnicos como Cartografías de la IDENTIDAD, LENGUA Y LENGUAJE VISUAL}

La presentación de mapas étnicos en los inicios del siglo XX resultó una modalidad recurrente para expresar en forma gráfica el resultado de lecturas cruzadas entre campos disciplinarios diferentes: lingüística, historia y arqueología. En efecto, la información arqueológica disponible constituía un anclaje geográfico y material para denominaciones étnicas coloniales; éstas, a su vez, brindaron el marco de referencia con el que denominar unidades estilísticas definidas a partir de la cerámica funeraria, cuyos lugares de procedencia servían como demarcadores de territorios lingüísticos (Boman 1923; Canals Frau 1940, 1953; Lafone Quevedo 1904; Márquez Miranda 1936, 1946; Serrano 1943; Vignati 1931). De esta forma, la etnicidad se encontró ligada estrechamente con la territorialidad, y así, la representación cartográfica fue una herramienta imprescindible en el trabajo científico (Quiroga 2003). La determinación de las unidades sociales se estableció sobre la identificación y correspondencia de unidades lingüísticas con denominaciones extraídas de los documentos coloniales de los siglos XVI y XVII. En tanto, la delimitación de los territorios étnicos provino de la identificación de rasgos culturales -estilos cerámicos- y su distribución geográfica, tomando como mapa base los límites territoriales fijados por los estados republicanos modernos. 
El discurso científico proyectó la percepción colonial propia de los siglos XVI y XVII sobre la dinámica étnica prehispánica, considerando que la mirada colonial no reflejaba las transformaciones que ella misma había generado, sino un estado de situación que continuaba, sin mayores modificaciones, las condiciones precoloniales. La variabilidad registrada en las urnas funerarias fue interpretada como expresión material y visual de identidades étnicas, asumidas como manifestaciones coloniales de un incuestionado origen prehispánico. Por esto planteo que la mirada científica asumió como válida -e hizo suya a principios del siglo XX-la perspectiva colonial.

La etnicidad fue identificada con el concepto de nación como principio de integración social basada en la comunidad cultural de sus integrantes. En este sentido, la unidad lingüística era el criterio de mayor relevancia para definir unidades sociales y culturales denominadas nación o etnia, según diferentes autores. Boman se refiere a los pueblos andinos como un área cultural homogénea, una zona étnica específica formada por los pueblos andinos asentados desde Ecuador hasta Argentina y Chile (1908: 3). Márquez Miranda asume como válidas y pertinentes las categorizaciones étnicas coloniales para hablar de una nación diaguita (1946: 7); Canals Frau considera que "...los pueblos son unidades cerradas, cual lo determina la uniformidad lingüística y cultural de sus componentes..." (1948: 61).

La lengua fue un criterio de primer orden aceptado por todos los investigadores, quienes coincidían en identificar la nación diaguita con una lengua común, el kakan. Los actores sociales protagonistas del pasado prehispánico se definían por su unidad lingüística y en segundo lugar -solo en segundo lugar- por rasgos estilísticos diferenciados de su cultura material. Así, el criterio de la unidad lingüística fue utilizado para diferenciar la población atacameña y chicha de los diaguitas valliserranos (Boman 1908, Vignati 1931).

Los extremos del territorio en el que se hablaba el kakan no fue establecido por las referencias lingüísticas de documentos coloniales, sino por los hallazgos de piezas estilísticamente asimilables a las urnas que -a juicio de los investigadores, claro está- identificaban a los diaguitas. Si las urnas expresaban una identidad asumida como homogénea, bastaría con ubicar geográficamente los hallaz- gos para representar, por medio de un polígono irregular, la extensión de una unidad cultural. Los hallazgos de cerámica diaguita en San Juan, hasta el Nevado del Acay, en Jujuy constituyen los extremos norte y sur del territorio diaguita (Canals Frau 1940; Debenedetti 1917; Márquez Miranda 1946: 8, Serrano 1940). Una línea de investigación proveniente de la arqueología abordó la deconstrucción de las áreas culturales y el pasado prehispánico del territorio conformado por los límites del Estado nacional incluyendo las áreas de puna y valles (Nastri 2011, Haber 1999, entre otros).

Desde el campo de la investigación etnohistórica Lorandi y Boixadós (1989) elaboraron un mapa étnico del área de calchaquí tomando como información de base las denominaciones étnicas encontradas en las probanzas de méritos y servicios, presentadas por los vecinos feudatarios de la gobernación en el contexto de las rebeliones. En este caso, los rótulos que identifican las unidades étnicas carecen de signos gráficos que establezcan sus límites (Harris 1997). Al mismo tiempo, plantearon una estrategia de análisis tendiente a conformar una territorialidad basada en la autoadscripción identitaria, asumiendo que las denominaciones coloniales serían una vía de acceso a la etnicidad del siglo XVII en el valle de Calchaquí. Una línea de reflexión teórica en antropología aboga por entender las relaciones de mayor escala antes que la definición de unidades culturales internamente homogéneas y segmentadas por límites precisos (Gupta y Ferguson 1992; Boccara 2003).

Si el trabajo pionero de Lorandi y Boixados (1988-1989) planteó una escala de análisis más detallada que la referencia general de Calchaquí -como se hacía hasta el momento de su publicación-, lo cierto es que a espaldas de aquellas sierras, en dirección a Atacama y hacia el sur, hacia La Rioja, se pueden observar redes sociales y políticas con una dinámica propia de resistencia. Me refiero a aquellos que la documentación colonial llamaba los indios de Londres, quienes seguían siendo identificados como diaguitas.

\section{$*$ Los indios de londres, provincia de los DIAGUITAS}

En tanto la antropología del siglo XX buscó definir la relación de identidad, cultura material y espacio en tér- 


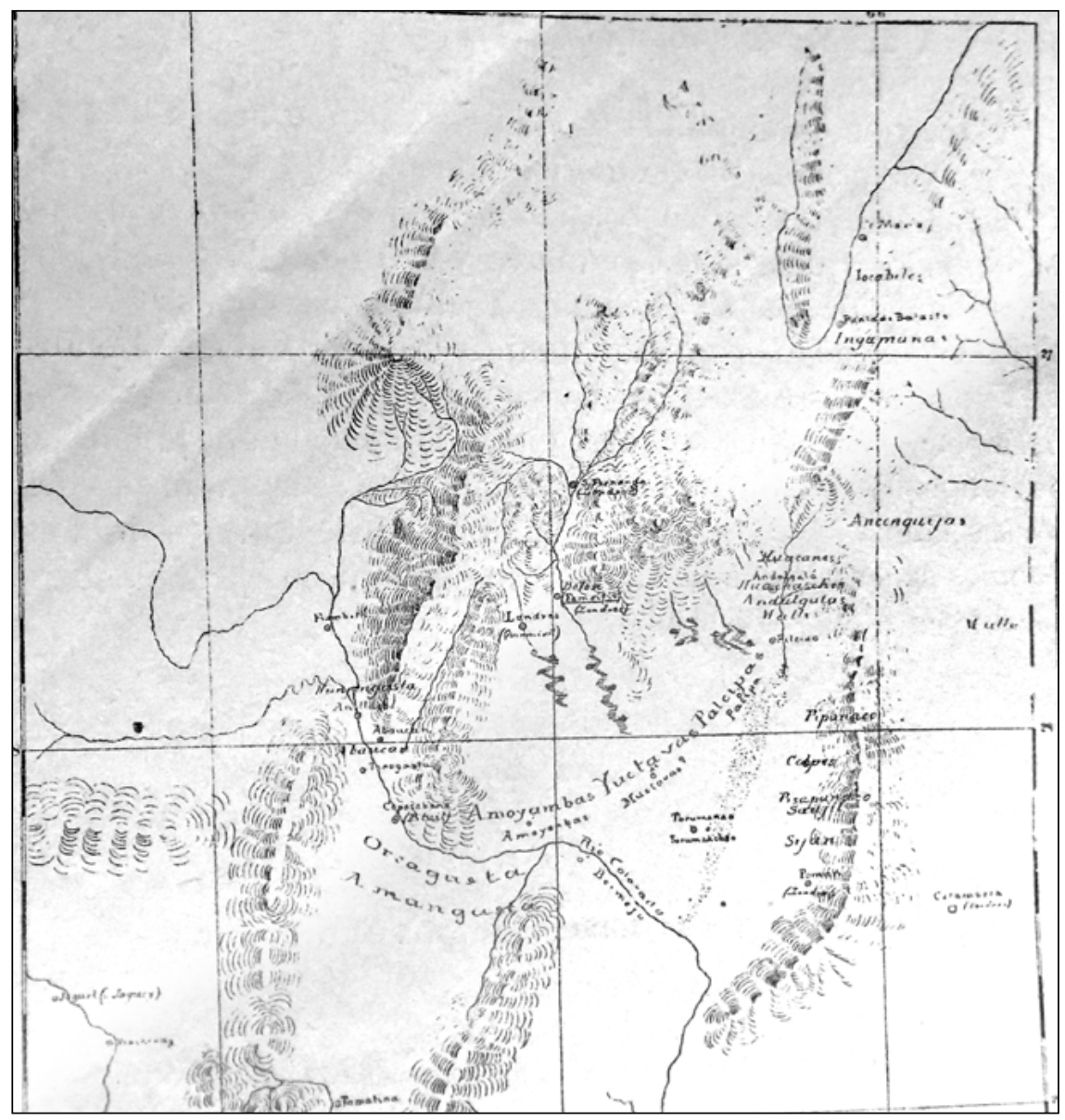

Figura 2. Croquis étnico de Londres. Reproducido de Lafone Quevedo (1896).

minos de áreas culturales, la historiografía colonial dirigió su interés hacia la conformación del Tucumán como gobernación inserta en el Virreinato del Perú. El nombre diaguita -caracterizados frecuentemente como indios de guerra- aparece en los relatos de la primera entrada de Diego de Almagro al noroeste argentino en 1535. Sin embargo, a lo largo del siglo XVI, la provincia de los diaguitas se identifica con la ciudad de Londres y su alcance jurisdiccional. Fundada por primera vez en 1558 por Juan Pérez de Zurita a orillas del río Famayfil, la ciudad sería refundada nuevamente en cuatro oportunidades debido a la resistencia de los indios, la aridez, el régimen estival de sus ríos y los conflictos internos de sus pobladores (Quiroga 2012, 2014). Aun así, las riquezas mineras de sus cerros y el secreto que guardaban los indios sobre su ubicación renovaban el interés por conservar la ciudad como avanzada colonial sobre territorios rebeldes a pesar de su inestabilidad.
En 1607 la provincia de los diaguitas se identificaba con el valle de Londres. Gaspar Doncel, teniente de gobernador, tuvo a su cargo la reedificación de la ciudad, con el nombre de San Juan Bautista de la Ribera. En respuesta a un interrogatorio de la Corona para tener noticia de la tierra, expresó: “...se llama la provincia de los diaguitas y está fundada en el valle de Famayfil que por otro nombre se llama el valle de Londres...". Sin embargo, dentro del mismo documento $-\mathrm{y}$ en otros producidos en el acto fundacional- las denominaciones específicas de cada grupo utilizadas para designar cada encomienda reemplazan al nombre genérico de diaguitas.

Uno de los primeros mapas étnicos de la región -publicado en 1896- pertenece al trabajo de Samuel Lafone Quevedo referido a la fundación de la ciudad de San Juan Bautista de la Ribera en 1607 (Figura 2). Su conocimiento de la toponimia regional le permitió elaborar 
una cartografía basada en la información contenida en la carta que el gobernador del Tucumán, Alonso de Ribera, dirigió al rey. En ella se mencionaba la situación de las encomiendas que se ubicaban dentro de la reactualizada Jurisdicción de Londres, cuya cabecera se refundaba con la intención de controlar un área de resistencia anticolonial recurrente (Quiroga 2012, 2014). Si bien la carta describía las condiciones de la fundación y mencionaba detalladamente a los integrantes de la hueste fundadora, Lafone Quevedo eligió cartografiar, solamente, a la población indígena de la zona y la ubicación de los enclaves fundacionales españoles.

La representación cartográfica - llamada croquis étnico de la fundación de Londres- buscaba sintetizar la información provista por el texto de 1607, asumiendo el supuesto de una continuidad histórica y coincidencia geográfica entre los nombres de las encomiendas del siglo XVII y la ubicación de los topónimos de fines del XIX. La posición y orientación de ríos y cordones montañosos sirvieron como rasgos estructurantes para confeccionar el mapa base. Entre ellos, se colocaron los rótulos que anclaban al terreno, tanto las ciudades coloniales como los nombres de pueblos encomendados. En el primer caso, un signo gráfico específico, de implantación puntual, marcaba la posición del enclave urbano. En el segundo, la extensión y orientación de la etiqueta servía para marcar áreas imprecisas, de límites desconocidos o, al menos, no visibles. El mapa de Lafone Quevedo cartografió la identidad étnica de acuerdo con la descripción de las encomiendas de 1607, asumiendo que sería posible homologar ambas realidades.

Desde el campo del análisis de los discursos coloniales, Martínez plantea recuperar las contradicciones que encierran los enunciados sobre las identidades andinas, tomando el contexto en el que se nombran, las capas discursivas del texto, así como la diacronía de sus referencias (2011: 16). La descripción de los pueblos en encomienda de 1607 -al fundarse la ciudad de San Juan Bautista de La Ribera- difiere sensiblemente respecto de los pueblos que articulan la resistencia del alzamiento general de 1630. Un seguimiento diacrónico de la documentación muestra cambios en la forma de presentar los nombres de las parcialidades que integraban los repartos.
En un trabajo previo reconstruimos la sucesión de la encomienda de Malfin y Andalgalá (Quiroga 2012). El liderazgo de los malfines en 1630 contrasta con su ausencia u omisión entre los pueblos encomendados de 1607. Recién en el año 1632, los expedientes que refieren la transmisión de la encomienda mencionan a los malfines, cuando el gobernador Felipe de Albornoz hace merced de la encomienda vacante de Yuctava, Nogolma, Andalgalá, Malfin y Asapates.

Una situación comparable se observa respecto de los abaucanes. Boixadós plantea un estudio del término abaucán como un topónimo que refiere al río que recorre de norte a sur el valle de Fiambalá (Catamarca), pero en 1607 denomina la encomienda de Hernando de Arisa integrada por el pueblo de Abaucán y Singuil (Ratto y Boixadós 2012: 205). Esta información contrasta con el padrón elaborado en 1627 en el que se jerarquiza el pueblo de Singuil sobre Abaucán. De modo que las referencias a los pueblos de encomienda, previas y posteriores al alzamiento general, son el resultado de una dinámica cambiante de traslados y reasentamientos merced a los repartos de los gobernadores en compensación por sus servicios en la guerra a los vecinos beneméritos. Precisamente si el ordenamiento de la población en encomiendas constituye una forma de organizar la mano de obra en función de intereses coloniales, las descripciones de los enfrentamientos y los escenarios de la guerra nos permiten observar las denominaciones coloniales en otro contexto, en la contingencia de rebelión. El desarrollo y desenlace de la rebelión puso en un lugar de protagonismo y visibilidad otras parcialidades y liderazgos.

\section{Un entramado rebelde}

En 1630 los indios de la jurisdicción de Londres se aliaron con sus vecinos del valle Calchaquí, en lo que se llamó el alzamiento general (Montes 1961: 96; Lorandi 1998; Schaposchnik 1997; Quiroga 2010). Los autores coinciden en señalar la causa de la rebelión en el peso de las prestaciones coloniales exigidas en trabajo e hilados bajo la forma del servicio personal (Quiroga 2012). Aunque partieran de las mismas fuentes documentales -las probanzas de méritos y servicios de los vecinos feudatarios, beneméritos de las ciudades de La Rioja, Salta y Tucumán-, la cartografía que acompañaba los trabajos citados enfatizó diversos aspectos del proceso histórico. 


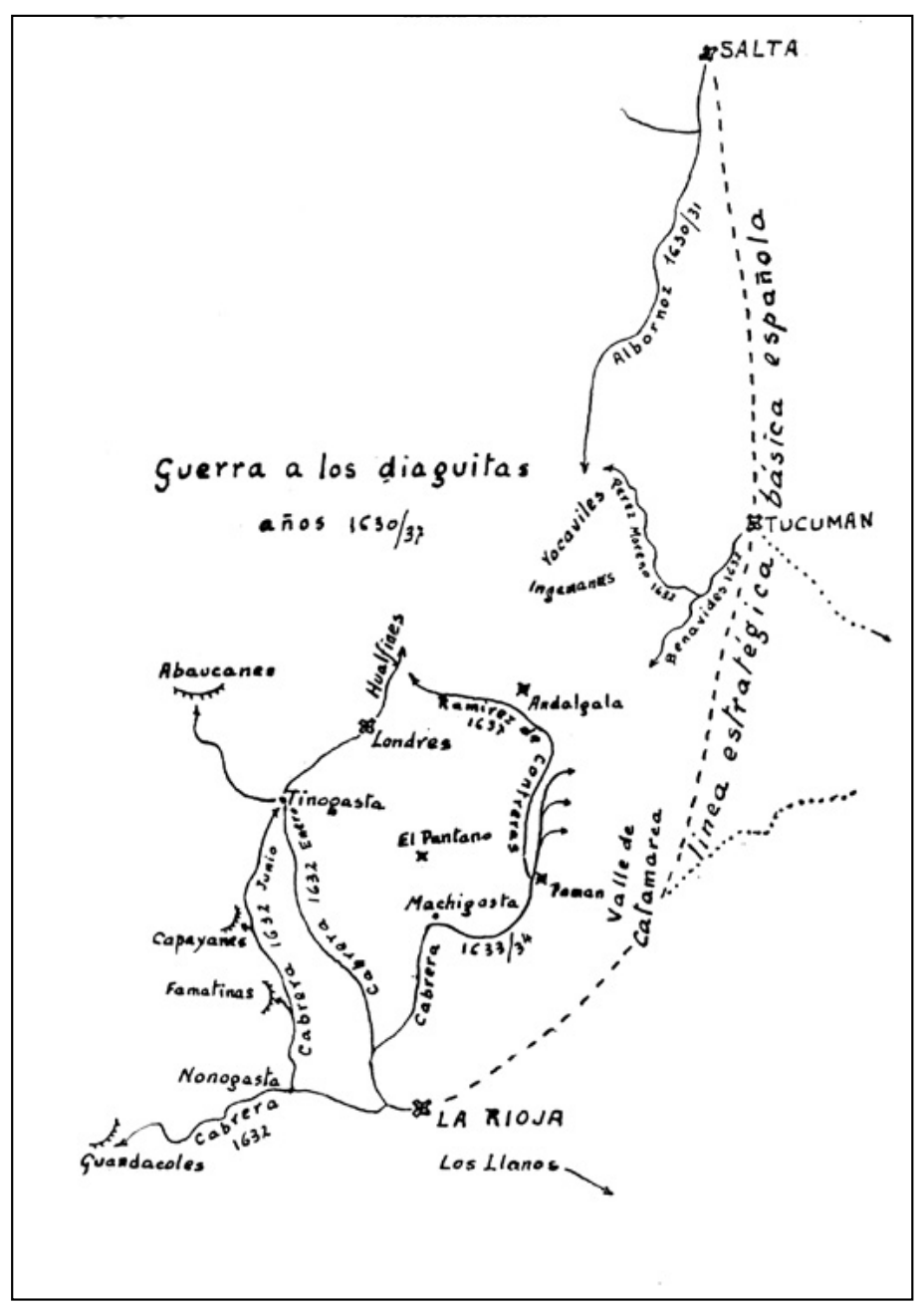

Figura 3. Entramados rebeldes.

Reproducido de Schaposchnik (1994, 1997, 1999).

Mientras que el estudio de Aníbal Montes (1959: 108) describe la estrategia de la guerra marcando los frentes de lucha en el período de 1630 a 1642, Schaposchnik se detiene en los aspectos políticos de la rebelión cartografiando la articulación territorial de las alianzas políticas y parentales de los actores de 1642 (Figura 3). A pesar de sus diferentes objetivos, la cartografía de ambos autores descansa sobre el mismo supuesto con el que Lafone Quevedo (1896) elaboró su croquis étnico a fines del siglo XIX. Me refiero a la distribución de la toponimia actual como criterio suficiente para ubicar en el terreno las denominaciones coloniales.

El trabajo fundante de Aníbal Montes sobre el alzamiento de 1630 plantea una cronología de los hechos del sector sur - en la ciudad de Londres y La Rioja- basada en las probanzas de méritos y servicios de los descendientes beneméritos de la Gobernación (documentación que guarda el Archivo Histórico Provincial de Córdoba) y las cartas del gobernador Felipe de Albornoz publicadas por Antonio Larrouy en 1923. Montes señala que el período de mayor conflictividad en ambos escenarios -valle de Calchaquí como escenario norte y Londres como escenario sur- se produce entre 1630 y 1638 cuando los malfines liderados por Chalimín - asedian las ciudades de La Rioja y Londres, cortando las tomas de agua que abastecían las ciudades. El traslado de la ciudad de Londres y la instalación de fuertes que cercaban el ámbito vallisto permitieron el ingreso de la hueste dirigida por Pedro Ramírez de Contreras, quien apresa y asesina a su líder en 1638. 
La represión del alzamiento general de 1630, encabezado por el gobernador Felipe de Albornoz y el enviado de la audiencia de Charcas, Antonio de Ulloa, trajo consigo la instalación del Fuerte del Pantano en el valle de Palcipas con el fin de controlar a los rebeldes de Londres (1633). Lo cierto es que el reparto de nuevas encomiendas a los beneméritos de la guerra -las de malfines y abaucanes entre otras- una vez finalizadas las rebeliones mantienen un precario equilibrio en las relaciones hispano-indígenas de la jurisdicción de Londres, al que se suman las misiones permanentes de Calchaquí desde 1643 y los fuertes-presidios erigidos para el control de los rebeldes sojuzgados.

Hacia 1643 , la resistencia de los malfines se limitaba, según Montes, a escaramuzas de escasa envergadura, sin embargo, al ampliar la documentación, incluyendo en el conjunto las probanzas que se encuentran en el Archivo de Indias, vemos que las formas de la resistencia protagonizadas por malfines y abaucanes no se detuvieron en 1643, sino que continuaron de modo recurrente, aunque sin lograr las alianzas de gran escala de la década pasada. En 1646 se atribuye a los malfines la muerte del cabo del Fuerte del Pantano Antonio Calderón cuando ingresa al interior del valle a obligar al cumplimiento de las prestaciones y a rescatar a los misioneros agustinos que predicaban entre malfines y abaucanes. .

La instalación de misiones permanentes en los valles buscaba lograr la conversión y control colonial del área asentados en los alrededores del Fuerte del Pantano. Hasta allí llegaban los misioneros itinerantes provenientes desde La Rioja, entre ellos, el jesuita Hernando de Torreblanca. Aun cuando las alianzas rebeldes y el ataque a las ciudades se habían aplacado, para 1642, los indios de Londres, entre ellos malfines y abaucanes, mantenían formas de resistencia. Si bien no estaban en condiciones de atacar los emplazamientos coloniales como en la década anterior, se resistían a cumplir con las mitas impuestas (Schaposchnik 1997; Quiroga 2010).

\section{Las misiones de Calchaquí}

A partir del año 1607 los valles y punas del Tucumán integraron la jurisdicción territorial de la recién creada Provincia jesuítica del Paraguay (Ávalos 2001, Morales 2005; Page 2010). Sin embargo, la presencia de misio- neros en Calchaquí se registra desde 1588 con el ingreso de Alonso Barzana en compañía del gobernador Ramírez de Velazco, con el objeto de lograr la conversión de los nativos. Una vez aplacada la rebelión de calchaquíes, pulares y diaguitas, se esperaba que la presencia de los jesuitas evitara la amenaza de los vallistos sobre las fundaciones urbanas. Se esperaba también que la presencia de los sacerdotes en el interior de los valles garantizara el cumplimiento regular de las prestaciones exigidas en los emprendimientos económicos de sus encomenderos (Rubio Durán 1999).

La resistencia de los indígenas a la conversión y la presión del estamento encomendero para acceder a los beneficios de la mano de obra que encerraban los valles redundó en que los emprendimientos misionales de 1601 y 1609 no lograran la estabilidad suficiente como para mantener su continuidad. En este campo, los misioneros constituyen actores protagónicos del conflicto suscitado por las formas abusivas del servicio personal, reclamando a las autoridades condiciones tributarias especiales, además de restringir el ingreso de españoles a los valles calchaquíes (Morales 2005: 60-62). Lo cierto es que adoptando la forma de misiones ambulantes o de residencia fija, la Orden se convierte en un actor protagónico de la política regional.

En 1643 se decide encauzar el emprendimiento misional, por medio de dos instalaciones estables en el interior del valle de Yocavil y de Calchaquí, la misión de Santa María y de San Carlos, respectivamente. A partir de su emplazamiento, la actuación de los jesuitas en la política regional deja su testimonio en la producción de informes destinados a las autoridades de la Orden conocidas como las Cartas Anuas (Morales 2005). La llegada de Pedro Bohorquez a Calchaquí abre un nuevo panorama de negociaciones y juego de intereses en las relaciones coloniales en el mes de mayo de 1657 (Lorandi 1997, Piossek Prebisch 1976).

Contando con el apoyo de los jesuitas como mediadores -quienes se negaban a permitir el ingreso de españoles en los valles-, Bohorques prometía a las autoridades revelar la ubicación de las minas enclavadas en los cerros y punas de la Gobernación. Las Juntas celebradas en Londres de Pomán, entre los caciques de Calchaquí, los jesuitas misioneros, el gobernador Mercado y Villacor- 
ta y Bohorques establecieron tres ítems principales de acuerdo: a) los curacas de Calchaquí se comprometían al cumplimiento de las prestaciones en tierras del encomendero y brindar la información de las riquezas mineras de la puna y huacas, b) Bohorques sería reconocido por las partes con el título de Inca y con jurisdicción civil y militar en el interior del valle, c) El valle Calchaquí se comprometía a no refugiar en su interior a los malfines y abaucanes provenientes de Londres.

Los acuerdos de Pomán rápidamente mostraron su fragilidad. En agosto de 1658, las autoridades apresaron a Bohorques bajo la sospecha de que había roto los arreglos políticos de la junta. Sin dar aviso al gobernador, había ingresado en tierras de malfines y famatinas en busca de las huacas y minas. Se ordenó su captura y este gesto político dio inicio a la rebelión que, ahora sí, incluía al valle Calchaquí aliado del entramado Malfin.

Los trabajos de Lorandi (1997) y Piossek Prebisch (1976) centraron sus observaciones en la dinámica política y militar de las campañas realizadas en los valles, pero una revisión de los expedientes coloniales muestra que la puna, como espacio minero, fue el foco de disputa. Para 1658 , la puna ya no es área de refugio o un páramo inhabitable -como las autoridades describían- sino el foco de los intereses coloniales como guarda de las riquezas mineras que los indios ofrecían enseñar a Bohorques.

En un trabajo previo observamos que a lo largo del siglo XVI la voz puna reemplaza al término páramo en los textos castellanos (Quiroga 2015). Si observamos el mapa de la Figura 1 vemos que el término Antiofac se inscribe en el sector que podemos identificar con el paisaje puneño de lagunas altoandinas. El estado de la investigación muestra el antecedente más temprano del término Antofagasta, en el deslinde jurisdiccional de la ciudad de San Juan Bautista de la Ribera en 1633, pero la referencia a un grupo de ese nombre se encuentra en el mismo expediente de la rebelión de 1658 que citamos anteriormente.

Entre los testimonios se menciona que la circulación de una flecha entre los curacas vallistos y puneños materializaba, según los testimonios coloniales, la formación de una alianza para la resistencia. De esta forma, los testigos declararon que desde Antofagasta había llegado la flecha que convocaba a la rebelión y fue recibida por los malfi- nes, enhebrando una alianza que, ante la ruptura de los acuerdos con el gobernador, incluía, ahora sí, a los calchaquíes:

...se han convocado todos ellos unos a dar en este valle, otros al Tucumán y aguardaban solamente al Inga para matarlo y luego a los Padres de Calchaqui de manera los que habian de venir a dar aquí han de ser abaucanes y malfines ingamanas para que ya dicen recibieron la flecha traída de Antofagasta...

La parcialidad de los Antofagasta vuelve a aparecer en la documentación en 1672 como aliados de los indios de Londres en relación con resistencias de baja conflictividad pero de gran eficacia a la hora de mantener la autonomía:

...por quanto a llegado a mi noticia que la parcialidad de los indios antofagastas conjunta a la jurisdicción de londres a tiempo anda retirada y fugitiva del comercio de los españoles y pueblos domesticos de indios de que a resultado retirarse a su abrigo muchos indios de los domesticos y de los nuevamente conquistados del valle de calchaquí...

La historiografía de la resistencia indígena en el Tucumán colonial elabora una cartografía de síntesis que visualiza y expresa, de modo gráfico, las conclusiones obtenidas a partir de los textos, pero como señalamos al inicio, los mapas coloniales permiten seguir el camino inverso; esto es, tomar la cartografía como fuente histórica, buscando en la representación visual una alternativa a la perspectiva que arrojan los documentos escritos (Harley 2005). En este caso retomaremos el análisis de la cartografía colonial planteando una revisión crítica sobre la relación entre topónimos y taxonomías coloniales.

\section{* La cartografía jesuítica del tucumán}

\section{El padre que mata la Luna}

La Carta Anua de 1653-54 menciona un caso peculiar de lo que los misioneros llamaron un "engaño piadoso" pergeñado con el fin de doblegar los ánimos rebeldes de los calchaquíes.. El misionero Diego Sotelo tomó las tablas astrológicas que tenía en la Misión de San Carlos y predijo a los vallistos el eclipse lunar que habría de ocurrir en fecha precisa e invitaba a los caciques a observar, 
en conjunto, el fenómeno astronómico. Cuenta el padre provincial, autor de este relato, que los calchaquíes asistieron y ante la confirmación del suceso frente a sus ojos gritaban: "Este padre mata la Luna". Ni aun así, pasado el suceso, los calchaquíes abandonaban sus antiguas costumbres, pero más allá de este hecho circunstancial cabe la pregunta: ¿Por qué había tablas astronómicas en una misión apartada de la provincia?

La formación de los jesuitas en disciplinas como la cosmografía y geografía proveyó especialistas que, sumado a la extensión de sus emprendimientos misionales, les permitió generar una producción cartográfica de escala continental, difícilmente equiparable por otras instituciones de su época (Buisseret 2006, Barcelos 2006, Millones Figueroa 2005). Sus mapas fueron elaborados con el fin de ilustrar las descripciones contenidas en las cartas anuas, o bien, de contar con información geográfica de áreas inexploradas. Pero la producción cartográfica trascendió la institución religiosa y sus obras fueron publicadas en Europa como parte de libros, atlas generales o bien, en forma aislada (Karrow 2006).

\section{El atlas de Joan Blaeu}

El mapa objeto de este trabajo lleva por título Paraquarial vulgo/Paraguay/cum Adjacentibus y representaba el Paraguay y Brasil, sumado a regiones vecinas como el Perú, Charcas, Chile y el Tucumán, el área de nuestro interés (ver Figura 1). Para este trabajo utilizo el ejemplar de 1662 digitalizado por la Biblioteca Nacional de España como parte del Atlas Mayor de Joan Blaeu, uno de los cartógrafos holandeses más importantes de su época. La obra se componía de 11 volúmenes dedicados al conocimiento geográfico y cartográfico del mundo conocido por los europeos. Este mapa estaba dedicado a Vicente Carrafa, quien se desempeñaba como séptimo general de la Compañía de Jesús, entre 1645 y 1649; por esto, esta pieza se incorpora a la producción cartográfica de la orden jesuítica, aun cuando se desconozca la versión original elaborada por la Orden (Furlong 1936, Buisseret 2006). Desconocemos qué elementos habrán sufrido modificaciones respecto de la obra original, tal como fuera elaborada por el cartógrafo jesuita, y más aún, el texto que seguramente acompañaría la pieza cartográfica.
Con respecto a los datos de edición encontramos en el sector inferior derecho la referencia de Ioannes Blaeu y la mención de Amsterdam como lugar de edición. En el centro, el nombre del grabador Gerard Coeck. De modo que su fecha de elaboración se restringe a los años que van desde 1645 hasta 1662, año de su publicación. Si ponemos esta pieza en contexto, al modo que Harley sugiere como metodología de análisis, cabe señalar que la obra publicada por su padre, William Blaeu en 1635, contenía otro mapa de la América meridional en el que se mencionan las regiones del Tucumán y Paraguay, sin las descripciones exhaustivas de las poblaciones nativas que vemos en el ejemplar de 1662 (Figura 4).

Si bien el análisis cartográfico de Furlong (1936) se centra en la autoría individual, lo cierto es que la producción cartográfica es el resultado de una serie de pasos técnicos en su ejecución, sumado a decisiones que organizan la expresión visual, síntesis de información y criterios de lo que sería relevante representar, en función de los sentidos creados en torno al paisaje. En el caso de la cartografía jesuítica hay una estructura institucional que produce cartografías funcionales a sus objetivos misioneros y políticos. La información generada por las actividades de sus misioneros se suma a un saber técnico, capaz de generar información geográfica y cartográfica que circula por medio de canales institucionales.

\section{Las capas de información, signos y rótulos}

La imagen digital se analizó buscando identificar las capas de información que componen el mapa y los signos cartográficos que se utilizan para representar aquellos aspectos considerados relevantes para la institución religiosa. Siguiendo los lineamientos metodológicos de Harley (2005), busqué contextualizar nuestro caso de estudio por medio de un análisis comparativo con los signos cartográficos utilizados en los mapas europeos del siglo XVII (Delano Smith 2006) y en segundo lugar, asumiendo una relación de continuidad entre el signo elegido y la naturaleza del fenómeno a cartografiar (Bertin 1979; Ferland 2000). 


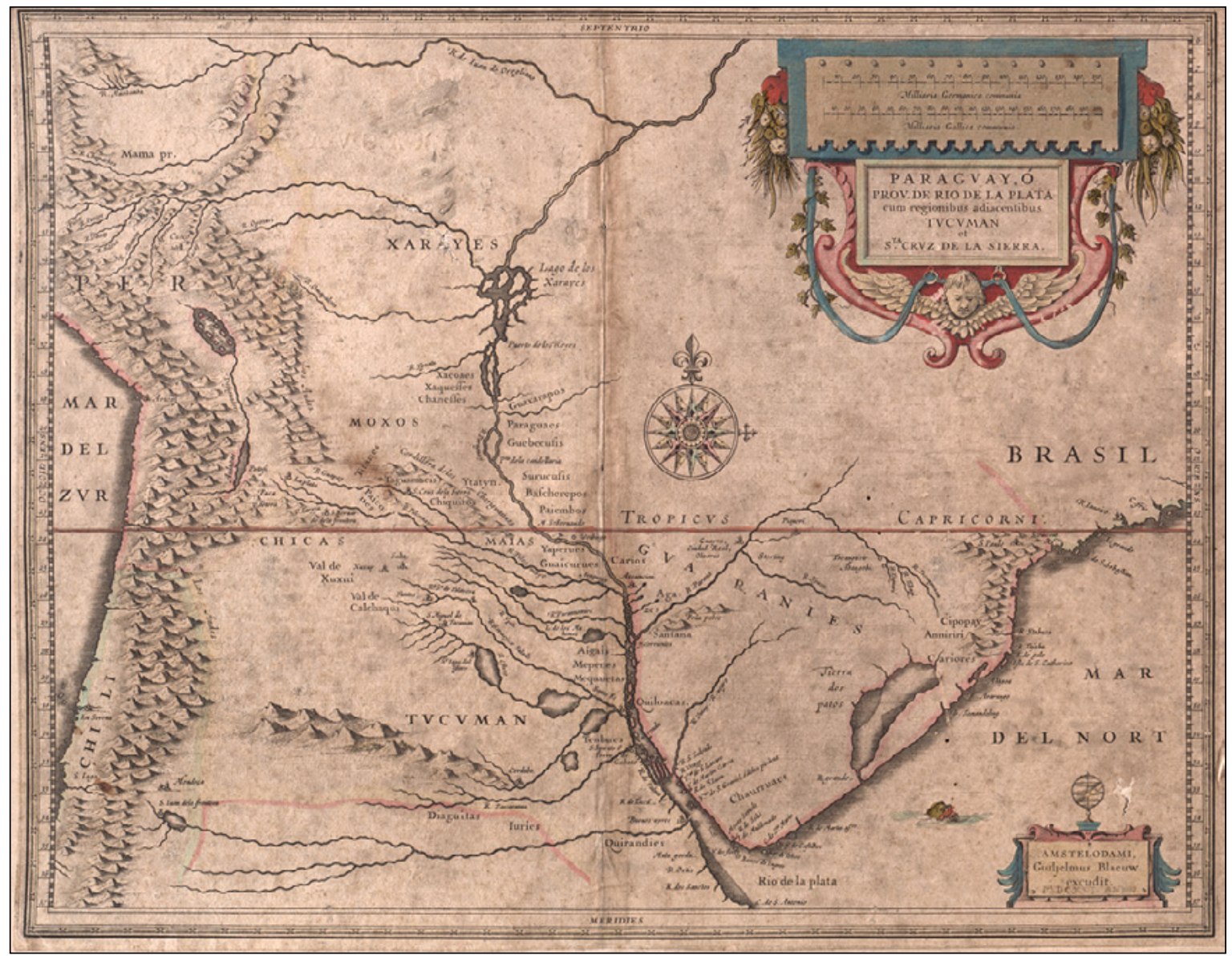

Figura 4. Theatrum orbis terrarum sive atlas novus in quo tabulae et descriptiones omnium regionum / editae a Guiljel et Ioanne Blaeu, 1635. Reproducido de la Biblioteca Nacional de España.

\section{Ambiente y paisaje}

La compilación de Delano Smith (2006) nos permitió identificar el carácter pictórico o ilustrativo de los signos cartográficos, en muchos casos similares a los que se utilizaban para representar ambientes y paisajes de la propia Europa (Figura 5). El sistema hidrográfico se representa por medio de un signo cartográfico lineal que cumple la función estructurante de la región. En nuestro caso, es relevante la diferenciación entre cuencas endorreicas y exorreicas como las que se observan en las áreas de puna y valles del Tucumán.

El sistema orográfico se representa con un signo de carácter pictórico y en perspectiva frontal, marcando la posición y orientación de los sistemas montañosos, sin referir variaciones altitudinales entre ellos. Para la vegetación se utiliza el mismo signo gráfico a lo largo de todo el continente sudamericano, acompañando el relieve de los montes. Si el registro de la naturaleza era una parte de las actividades de registro científico emprendido por los misioneros (Millones Figueroa 2005), la ausencia de una gráfica que expresa la diversidad ecológica del continente sudamericano es un silencio elocuente.

La contigüidad y homogeneidad que observamos entre orografía y vegetación describe el entorno de los montes, al que se identificaba con el lugar de las idolatrías y borracheras (Quiroga 1998, Castro 2002). La tierra alzada y fragosa, como rescata Martínez para Atacama y el Tucumán (2011), por su parte, refuerza esta noción de un paisaje animado por la idolatría en el que la acción misional tendrá, precisamente, la misión de transformarlo. La capa de información referida al ambiente y paisaje se expresa como un entorno homogéneo a lo largo del subcontinente para describir una geografía a evangelizar. 

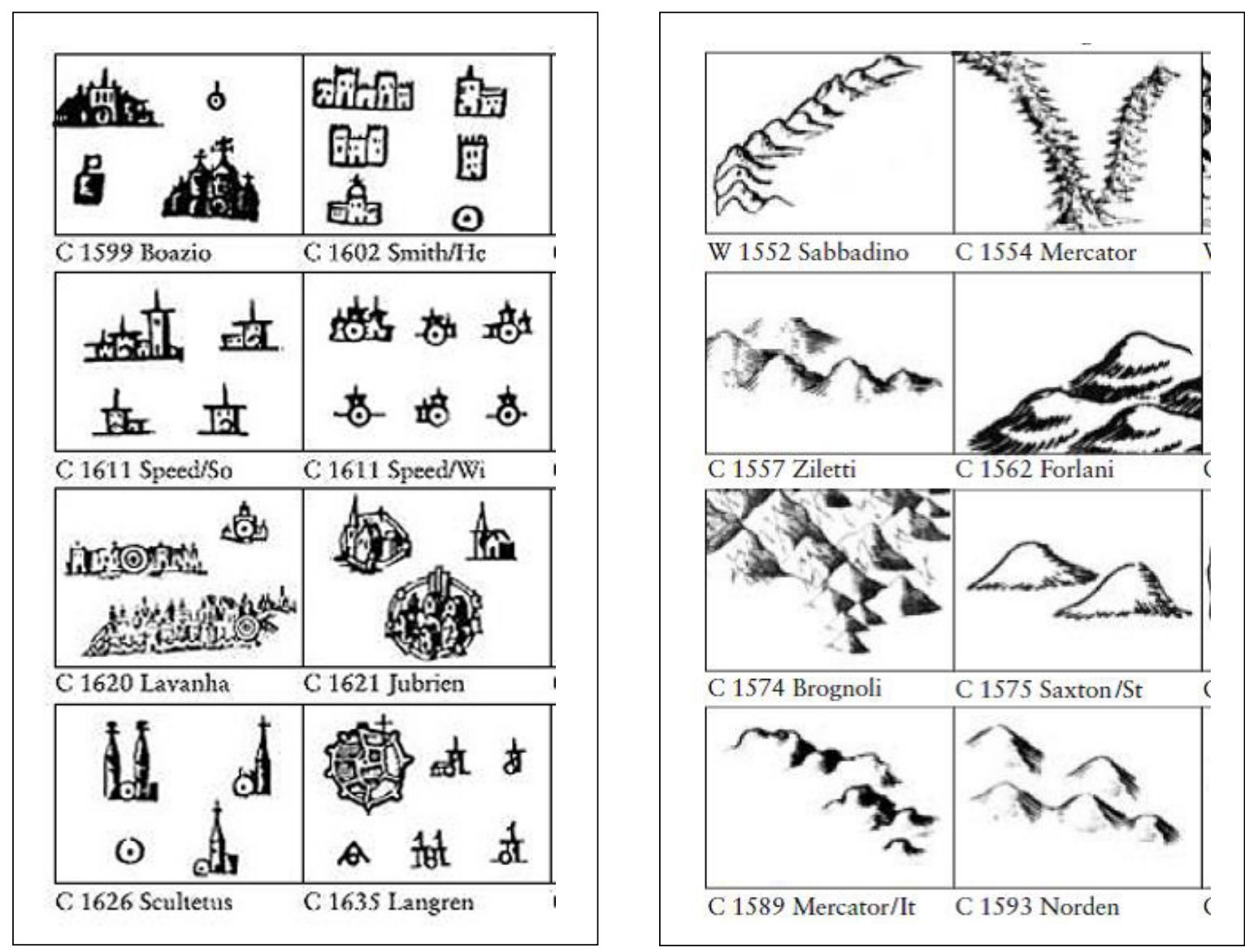

Figura 5. Signos cartográficos. Reproducido de Delano Smith (2007).

$\underline{\text { Referencias de poblamiento }}$

El recuadro de referencias que aparece en el ángulo inferior izquierdo muestra dos capas claramente diferenciadas para describir las instalaciones generadas por un poblamiento colonial -que incluye doctrinas y reducciones- respecto del asentamiento indígena de distribución incierta o desagregada: ciudad, ciudad destruida, Reducción, Fuerte, asientos inciertos de infieles.

Los asentamientos coloniales se marcan como puntos en el espacio a través de signos cartográficos diferenciados entre ciudades, ciudades destruidas y reducciones. En tanto, los indios infieles presentan una ubicación incierta, donde la distribución de una trama formada por pequeños triángulos carece de un signo gráfico lineal que delimite el área. Se trata entonces de dos formas de representar la espacialidad que construyen ambos segmentos de la sociedad colonial. La agregación y desagregación del asentamiento constituye la divisoria entre ambos. Al igual que en el caso anterior, no es el desconocimiento de las áreas cartografiadas lo que explica un asentamiento calificado como incierto, pues el modo de habitar de los indígenas era motivo frecuente de las descripciones contenidas en las cartas de misioneros.

Así como la capa referida al ambiente describe un paisaje de montes ligado conceptualmente a las idolatrías, el asentamiento agregado -opuesto al asentamiento disperso- representa otra noción clave para la mirada colonial, esto es, "vivir en policía" bajo autoridades que resguarden el orden social, transformando el modo de habitar y las costumbres de su gentilidad, como expresó por ejemplo el Concilio Limense de 1573 en el que la orden jesuítica, en la figura del padre Acosta, tuvo especial actuación (Estenssoro 2003). Si comparamos la 
descripción del asentamiento entre la región de Charcas y el Tucumán, se observan en el primer caso tan solo las ciudades y reducciones. Según esta representación, el área de Charcas se mostraba como un universo colonial que respondía al ordenamiento reduccional toledano y a la diferenciación anhelada por las autoridades de una república de indios separada de la república de españoles (ver Figura 4).

\section{Rótulos}

Las misiones de residencia fija fueron instaladas en el área de los valles desde 1643 (Amigó 2001; Ávalos 2001; Page 2010), de modo que las descripciones y referencias más detalladas aparecen con respecto a los habitantes de Calchaquí. Sin embargo, observando el tratamiento gráfico de la tipografía, este mapa jerarquiza la dinámica política y/o identitaria de los indios de la jurisdicción de Londres, ubicada a espaldas de Calchaquí, recostada sobre la cordillera de Chile.

Los rótulos constituyen un tercer elemento central en este mapa. No solo por el detalle de los pueblos mencionados, sino también por los recursos visuales que crean paisajes a partir del tratamiento gráfico de las etiquetas (Lois 2010). La tipografía se utiliza como recurso para marcar selectividad y asociación en términos cartográficos, es decir, agrupar por similitud y, al mismo tiempo, percibir las diferencias cualitativas del fenómeno a cartografiar (Ginzburg 1983).

Si comparamos la distribución de los rótulos de 1647 con la ubicación actual de los mismos topónimos, observamos variaciones en la distribución de las etiquetas consignadas en los mapas. A primera vista podría tratarse de un equívoco cartográfico al ubicar Malfin sobre la cordillera, a la izquierda de Abaucán y Andalgalá, alterando la distribución actual de estas localidades. Si aceptamos que se trata de un plano muy detallado producido por actores coloniales que tienen un buen conocimiento del terreno, como fueron los jesuitas, dada la existencia de misiones itinerantes y permanentes en el corazón de los valles calchaquíes, es pertinente plantear que no se trata de un error.

Si observamos el segmento de nuestro interés (ver figura 6), se diferencian claramente los rótulos del valle Calcha-

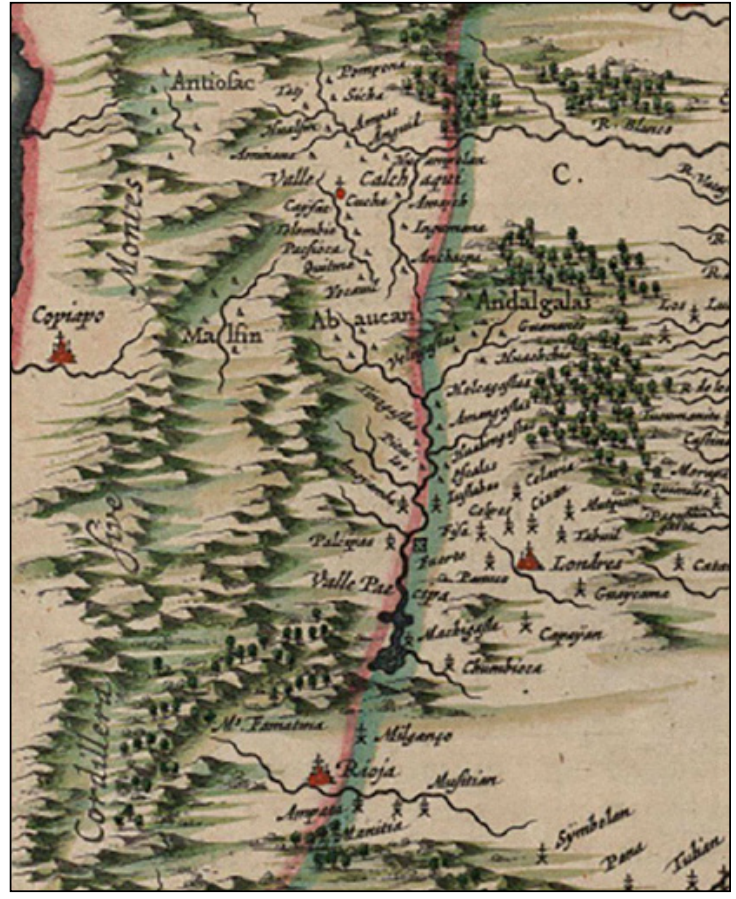

Figura 6. Detalle del área de Antiofac, Abaucán, Malfin y Andalgalá. Paraquaria/vulgo/Paraguay/cum Adjacentibus. En: America, quae est Geographiae Blavianae: Pars Quinta, Liber Unus. Volumen Undecimum. Amsteladami, 1662. Reproducido de la Biblioteca Nacional de España.

quí respecto de otros que denominan, con letras de mayor envergadura, Antiofac, Malfin, Andalgalá y Abaucán. ¿A qué se debe esta diferenciación? Qué busca expresar a través de estas etiquetas y a qué se debe su distribución? No hay ninguna referencia específica en el mapa que nos permita acercar alguna interpretación desde la gráfica, sabiendo además, que no estamos frente a un original sino a una reproducción o reelaboración cuyo texto no está presente y el que aporta el atlas no brinda descripciones específicas del sector, sino del Tucumán en general. La forma visual de la tipografía enlaza entre sí ciertos rótulos que, a su vez, carecen de un signo gráfico específico que los fije al terreno. Por eso sostengo que no se trata de una distribución geográfica de topónimos sino de un enunciado tomado de los textos escritos - en el que el orden de su enunciación rescata el liderazgo de los malfines en la rebelión-, ubicado en un área de límites imprecisos.

Entonces es pertinente seguir el camino inverso del que hablamos al inicio del trabajo, esto es del análisis cartográfico a los textos coloniales. La lectura de la docu- 
mentación histórica, en particular los escritos de la orden jesuítica, nos permite brindar una respuesta a esta pregunta generada por la cartografía. Al igual que el mapa de la Figura 1, esta cita nos permite observar que los indios de Londres se asocian con los de la puna en términos de alianzas políticas, como vemos tanto en los textos citados como en el mapa. Por eso no se trata de una cartografía de identidades y topónimos sino de redes políticas que atienden a la distribución geográfica de los actores coloniales y las formas de su vinculación. Por lo tanto sostengo que la cartografía que analizamos expresa, por medios gráficos, una descripción política del paisaje en la que se representan las redes de relaciones -sus alianzasentre los grupos cartografiados.

\section{* La cartografía política de la Resistencia}

Iniciamos este trabajo indagando en la expresión cartográfica del siglo XVII con el fin de aportar al debate sobre el significado de las denominaciones coloniales, no solo desde las fuentes escritas, sino también desde la cartografía histórica como otra forma discursiva (Lois 2000). Entonces iqué sentido adquiere la palabra política en este contexto? El mapa publicado por Blaeu -seguramente tomado de la producción cartográfica jesuítica- expresa la transformación del espacio generada por un proceso de conquista en el siglo XVI y, en forma específica, la política misionera en el Paraguay y Tucumán en el XVII. Este trabajo nos permitió recuperar distintas capas de información, en especial, la relación entre rótulo y paisaje como superposición de sentidos, en el que la tierra "alzada y fragosa" es parte constitutiva de una tierra de resistencia (Martínez 2011).

El interés colonial por las riquezas mineras de la puna, expresado con mayor claridad en el levantamiento de 1658 , se manifiesta en una cartografía donde las tierras más altas recostadas sobre la cordillera adquieren entidad y se nombran con nombres propios, dejando atrás la referencia genérica de páramos o despoblados. La puna, y antiofac en particular, constituye puntos de interés específico que los agentes coloniales consideran necesario denominar y ubicar en el terreno en el mapa de 1662, algo que está ausente en las ediciones previas. Lo cierto es que la cartografía nos permitió recrear imaginarios en torno a la región $y$, al mismo tiempo, rescatar una forma de referirse a ella superando la dicotomía de mapas étnicos o toponímicos.
La capa referida al asentamiento $-y$ aquí la instalación colonial se representa a sí misma- se muestra como diversa, agregada y en orden, opuesta a la desagregación y al desorden que representa una trama sin límites precisos utilizada para cartografiar a los indígenas. Por último, la tipografía describe pormenorizadamente no solo denominaciones generales como calchaquíes, chiriguanos u otros, sino que debajo de aquellos nombres genéricos aparecen categorizaciones, presumiblemente de menor jerarquía, pero imprescindibles a la hora de entender las dinámicas sociopolíticas del Tucumán. En estos términos, desde la heterogeneidad de los actores, la agencia de los paisajes y la historicidad de su conformación construimos - desde un mapa ya conocido pero escasamente problematizado - la dinámica de las resistencias desde el paisaje y a través de él.

Coincido con Schaposchnik (1997) cuando analiza la dinámica de alianzas de 1630 y 1642 en términos de entramado y que ésta tuviera su expresión en el terreno, pero la cartografía colonial expresó esta relación sin anclar los nombres a un punto preciso en el espacio, lo que nos permitió no solo replantear la relación entre denominaciones y topónimos, sino también la forma de construir territorio y, en ese sentido, relatar otra versión del mismo proceso.

La lectura de la documentación y la forma de representar a los grupos en el mapa nos permite pensar una territorialidad construida desde la práctica política de la alianza y el parentesco, desde la capacidad de generar redes desde y a través del paisaje de punas y valles. La circulación de bienes y personas nos muestra que los territorios de los indios de Londres no solo se establecían a partir de los grandes centros conglomerados de Malfin, Abaucán o Andalgalá como puntos fijos y precisos en el espacio, sino también, desde sus formas dinámicas de articulación social y política a lo largo de valles y punas, difícilmente cartografiable por quienes construían un paisaje que hacía del "vivir en policía" la forma material, cultural y política del dominio. 


\section{* Referencias citadas}

AMIGÓ, M.F. 2001. Carta Anua de la Provincia del Paraguay 16531654. Memoria Americana, 10: 177-235.

ARNOLD, D. 2000. La naturaleza como problema histórico. El medio, la cultura y la expansión de Europa. FCE, México.

ÁVALOS, C. 2001. La guerra por las almas. El proyecto de evangelización jesuita en el Tucumán temprano. Siglo XVII. Centro Educativo de San Lorenzo, Salta.

BARCELOS, A. 2006. Indios e jesuítas na exploração e colonização do espaço americano. X Jornadas Internacionales sobre Misiones Jesuíticas, Page, C. (Ed.), pp. 103-108. Universidad Católica de Córdoba, Córdoba.

BENEDETTI, A. 2003. Puna de Atacama. Sociedad, economía y frontera. Alción Editora, Córdoba.

BERTIN, J. 1979. Un test de base de la gráfica. Memoria del I Seminario Sudamericano sobre Cartografía Temática. Instituto Geográfico Militar, Buenos Aires. pp. 60-79.

BOCCARA, G. 2003. Fronteras, mestizaje y etnogénesis en las Américas. En Las fronteras hispanocriollas del mundo indígena latinoamericano en los siglos XVI-XIX. Raúl Mandrini y Carlos Paz (Comps.), Universidad Nacional del Comahue, Neuquén, pp. 63-108.

BOMAN, E. 1908. Antiquités de la région andine de la République Argentine et du désert d'Atacama. París.

BOMAN, E. 1923.Los ensayos para establecer una cronología prehispánica en la región diaguita (República Argentina). Boletín de la Academia Nacional de la Historia, Quito. Tomo VI, pp. 1-31.

BRIZUELA DEL MORAL, F. 2002. Jurisdicción territorial de Catamarca. Congreso Regional de Ciencia y Tecnología. Secretaría de Ciencia y Tecnología Universidad Nacional de Catamarca.

BUISSERET, D. 2007. Spanish Colonial Cartography, 1450-1700. En The History of Cartography, Woodward, D. (Ed.), vol. 3, Cartography in the European Renaissance. University of Chicago Press, pp. 1143-1171.

CANALS FRAU, S. 1940. El límite austral de los Diaguitas. Publicaciones del Museo Etnográfico de la Facultad de Filosofía y Letras, UBA, Buenos Aires, serie A, IV: 117-139.

CANALS FRAU, S. 1948. Raza, pueblo, nación. Anales del Instituto Étnico Nacional. Buenos Aires. Vol. 1, pp. 57-62.

CARMIGNANI, L. 2012. Política colonial y sociedades indígenas en la Gobernación del Tucumán. El Gobernador Alonso de Ribera, los tenientes de Naturales y la elite encomendera durante la vigencia de las Ordenanzas de Abreu, Tesis de Licenciatura en Historia, Universidad Nacional de Córdoba.

CASTRO OLAÑETA, I. 2002. Recuperar las continuidades y transformaciones: las juntas y borracheras de los indios de Quilino y su participación en la justicia colonial. En Los pueblos de indios del Tucumán colonial: pervivencia y desestructuración. Faberman y Montero (Comps.). UNQ. Quilmes, pp. 175-202.

CASTRO OLAÑETA, I. 2010. Servicio personal, tributo y conciertos en Córdoba a principios del siglo XVII. Memoria Americana. Cuadernos de Etnohistoria, 18-2: 101-127

COSGROVE, D. 2008. Cultural cartography: maps and mapping in cultural geography. Annual Géographie, 660-661: 159-178.
CRAIB, R. 2000. Cartography and power in the conquest and creation of New Spain. Latin American Research Review, 35(1): 7-36.

CRUZ, R. 1997. La "construcción" de identidades étnicas en el Tucumán colonial: los amaichas y los tafies en el debate sobre su "verdadera" estructura étnica. En Ana María Lorandi (Comp.), FFyL, UBA, Buenos Aires. El Tucumán Colonialy Charcas, I: 309-340.

DEBENEDETTI, S. 1917. Investigaciones arqueológicas en los valles preandinos de la provincia de San Juan. Publicaciones de la Sección Antropología. Facultad de Filosofía y Letras, 15. Buenos Aires.

DELANO-SMITH, C. 2007. Signs on Printed Topographical Maps, ca. 1470 - ca. 1640. The History of Cartography, Woodward, D. (Ed.), vol. 3, Cartography in the European Renaissance. University of Chicago Press, Chicago, pp. 28-590.

ESTENSSORO, J.C. 2003. Del paganismo a la santidad. IFEA, Universidad Católica del Perú, Lima.

FERLAND, Y. 2000. Les défis théoriques posés à la cartographie mènent à la cognition. Cybergeo: European Journal of Geography [En ligne], Dossiers, Colloque "O ans de sémiologie graphique", document 148 , mis en ligne le 17 novembre 2000 , consulté le 8.10.2015. URL: http://cybergeo.revues.org/499; DOI: $10.4000 /$ cybergeo.499

FURLONG CARDIFF, G. 1936. Cartografía jesuitica del Río de la Plata. Buenos Aires, Peuser. Publicaciones del Instituto de Investigaciones Históricas. Número LXXXI.

GINZBURG, J. 1983. Elementos de cartografía aplicada al tratamiento de la información. Instituto de Geografía. Serie: Contribuciones. Facultad de Filosofía y Letras. Universidad de Buenos Aires, Buenos Aires.

GIUDICELLI, C. 2008. Encasillar la frontera. Clasificaciones coloniales y disciplinamiento del espacio en el área diaguitocalchaquí (S. XVI-XVII), Nuevo Mundo Mundos Nuevos. http:// nuevomundo.revues.org $/ 56802$

GIUDICELLI, C. 2009. Calchaquí ou le syndrome de Ferdinandea Nuevo Mundo Mundos Nuevos [En ligne], Colloques, mis en ligne le 25.11.2009, consulté le 8.10.2015. http://nuevomundo.revues. org/57650; DOI: $10.4000 /$ nuevomundo. 57650

GUPTA, A. y FERGUSON, J. 1992. Space, Identity and the Politics of Difference. Cultural Anthropology, vol. 7, núm. 1: 6-23. Edición en castellano: Antípoda 7, julio-diciembre de 2008: 233-256.

HABER, A.F. 1999. Una arqueología de los oasis puneños. Domesticidad, interacción e identidad en Antofalla, primery segundo milenios d.C. Tesis doctoral inédita. Facultad de Filosofía y Letras, UBA.

HABER, A. y LEMA, C. 2006. La pura opinión de Vladimiro Weisser y la población indígena de Antofalla en la Colonia temprana. Intersecciones en Antropología 7: 179-191.

HARRIS, O. 1997. Los límites como problema: mapas etnohistóricos de los Andes Bolivianos. Travaux et mémoires. Saberes y memorias en los Andes. In memoriam Thierry Saignes. Éditions de l'IHEAL, París, pp. 351-573.

HARLEY, D. 2005. Textos y contextos en la interpretación de los primeros mapas. En La nueva naturaleza de los mapas. FCE, México, pp. 59-78. 
INGOLD, T. 2007. Materials against materiality, Archaeological Dialogues, 14(1): 1-16.

KARROW, R. 2006. Centers of Map Publishing in Europe, 14721600. The History of Cartography, Woodward, D. (Ed.), vol. 3, Cartography in the European Renaissance. University of Chicago Press, Chicago, pp. 611-621

LAFONE QUEVEDO, S. 1896. Refundación de la ciudad de Londres en 1607 en Belén. Boletín del Instituto Argentino geográfico, tomo XVII, Cuadernos 7, 8 y 9. Separata. Imprenta Roma, Buenos Aires, pp. 4-21.

LAFONE QUEVEDO, S. 1904. Tipos de alfarería en la región diaguito-calchaquí. Revista Museo de La Plata. Tomo XV, 2: 295-396.

LEMA, C. 2012. El mineral de Incahuasi. Oro e historia en la encrucijada colonial. Tesis para optar al grado de doctora en Ciencias Humanas. Universidad Nacional de Catamarca.

LOIS, C. 2000 . La elocuencia de los mapas: un enfoque semiológico para el análisis de cartografías. Doc. Análisis Geográfico, 36: 93-109.

LOIS, C. 2010. Paisajes toponímicos. La potencia visual de los topónimos sobre la Patagonia en la segunda mitad del siglo XIX. Mapas de la mitad del mundo. La Cartografía y la construcción territorial de los espacios americanos. Siglos XVI-XIX. Francisco Roque de Oliveira y Héctor Mendoza Vargas (Coords.), Centros de estudios geográficos. México- Lisboa, pp. 317-343.

LOIS, C. 2012. ¿Desde la periferia? Enfoques y problemas de la agenda actual sobre la historia de la cartografía en América Latina. Espacio tiempo 7: 14-29.

LORANDI, A.M. y Boixadós, R. 1987-88. Etnohistoria de los valles Calchaquíes, siglos XVI y XVII. Runa, XVII-XVIII: 263-419.

LORANDI, A.M. 1988. La resistencia y rebeliones de los diaguitacalchaquí en los siglos XVI y XVII. Revista de Antropología 3: 3-17.

LORANDI, A.M. 1988. El servicio personal como agente de desestructuración en el Tucumán colonial. Revista Andina 6: 135-173.

LORANDI, A.M. 1997. De Quimeras, rebeliones y utopías. La gesta del Inca Pedro Bohorques. PUCP, Lima.

MÁRQUEZ MIRANDA, F. 1946. Los Diaguitas. Inventario patrimonial arqueológico y paleo-etnográfico. Revista del Museo de La Plata (Nueva Serie). Instituto del Museo de la Universidad Nacional de La Plata. Antropología, 17. Tomo III.

MARTÍNEZ, J.L. 2011. Gente de la tierra de guerra. PUCP, Lima.

MILLONES FIGUEROA, L. 2005. El saber de los jesuitas, historias naturales y el Nuevo Mundo. Vervuert - Frankfurt - Iberoamericana, Madrid.

MONTES, A. 1961. El gran alzamiento diaguita (1630-1643), Revista del Instituto de Antropología, I: 89-159.

MORALES, M. 2005. A mis manos han llegado. Cartas de los PP Generales a la antigua Provincia del Paraguay (1608-1639). Monumenta Historica Societatis Iesu. Series Nova, vol. 1. Madrid-Roma.

NASTRI, J. 2011. Lo mismo, lo otro, lo análogo. Cosmología y construcción histórica a partir del registro iconográfico santamariano. Boletín del Museo Chileno de Arte precolombino, vol. 16, núm. 2: 27-48.

PAGE, C. 2010. La evangelización jesuítica en el Valle Calchaquí. Hacia la idealización de un nuevo hábitat jesuítico calchaquí. Tempo da Ciencia, vol. 17, núm. 33: 25-56.
PALOMEQUE, S. 2000. El mundo indígena. Siglos XVI-XVIII. En Tandeter, E. (Dir.), La Sociedad Colonial. Nueva Historia Argentina. Buenos Aires, pp. 87-145.

PIOSSEK PREBISCH, T. 1976. La rebelión de Pedro Bohorquez. Juárez Editor, Buenos Aires.

QUIROGA, L. 2003. Belén: Debates en torno a la construcción de un objeto de estudio. Runa, 24: 151-171.

QUIROGA, L. 2010. En sus Huaycos y Quebradas: Formas Materiales de la Resistencia en las Tierras de Malfin. Memoria Americana 18(1 y 2): 185-209.

QUIROGA, L. 2012. Las granjerías de la tierra: Actores y escenarios del conflicto colonial en el valle de Londres (Gobernación del Tucumán) (1607-1611), Surandino Monográfico, 2.

QUIROGA, L. 2014. La descripción política de los paisajes americanos: La relación geográfica de 1604 en la provincia de los diaguitas (Gobernación del Tucumán, Virreinato del Perú).Melanges. Casa de Velázquez. En prensa.

QUIROGA, L. 2015. Del páramo a la puna. Cartas, Relaciones geográficas y contextos arqueológicos para una descripción del paisaje altoandino en la Gobernación del Tucumán (1583-1611). Ponencia presentada al Encuentro / Debate La producción de conocimientos e interdisciplina. Arqueología, antropología e historia. Revista CORPUS, Archivos de la Alteridad Americana. Coordinadoras: Roxana Boixadós (UBA/UNQ/Conicet) y Norma Ratto (UBA/Museo Etnográfico).

RAFFINO, R. 1988. Poblaciones Indígenas Argentinas. TEA, Buenos Aires.

RATTO, N. y BOIXADÓS, R. 2012. Arqueología y Etnohistoria. La construcción de un problema de investigación (Abaucán, Tinogasta, Catamarca). Memoria Americana 20(2): 187-220.

RUBIO DURÁN, F. 1999. Punas, valles y quebradas: Tierra y trabajo en el Tucumán colonial. Siglo XVII. Diputación de Sevilla, Sevilla.

SCHAPOSCHNIK, A.M. 1997. Aliados y parientes. Los diaguitas rebeldes de Catamarca durante el gran alzamiento. En Ana María Lorandi (Ed.), El Tucumán Colonial y Charcas, FF y L, UBA, Buenos Aires. Tomo I, pp. 309-340.

SCOTT, H. 2006. Rethinking landscape and colonialism in the context of early Spanish Peru. Environment and Planning: Society and Space, 24: 481- 496.

SERRANO, A. 1947. Los aborígenes argentinos, sintesis etnográfica. Nova, Buenos Aires.

SICA, G. 2003. ¿De qué Norte hablamos? Las percepciones históricas del espacio y sus consecuencias en la investigación de las sociedades prehispánicas y coloniales del noroeste argentino. Memoria Americana 11: 51-72.

SLUYTER, A. 2002. Colonialism and Landscape. Duke University Press, Duke.

VIGNATI, M. 1931. Los elementos étnicos del noroeste argentino. Notas preliminares del Museo de La Plata I, 115-157.

WOODWARD, D. 2007. Techniques of Map Engraving, Printing, and Coloring in the European Renaissance. Woodward, D. (Ed.), vol. 3, Cartography in the European Renaissance. University of Chicago Press, Chicago, pp. 591-610. 